\title{
MEMBERIKAN PENDALAMAN KREATIFITAS GURU DALAM PEMBELAJARAN SAINTIFIK
}

\author{
M. Hery Yuli Setiawan, Feri Faila Sufa \\ Universitas Slamet Riyadi \\ Heary3030@gmail.com
}

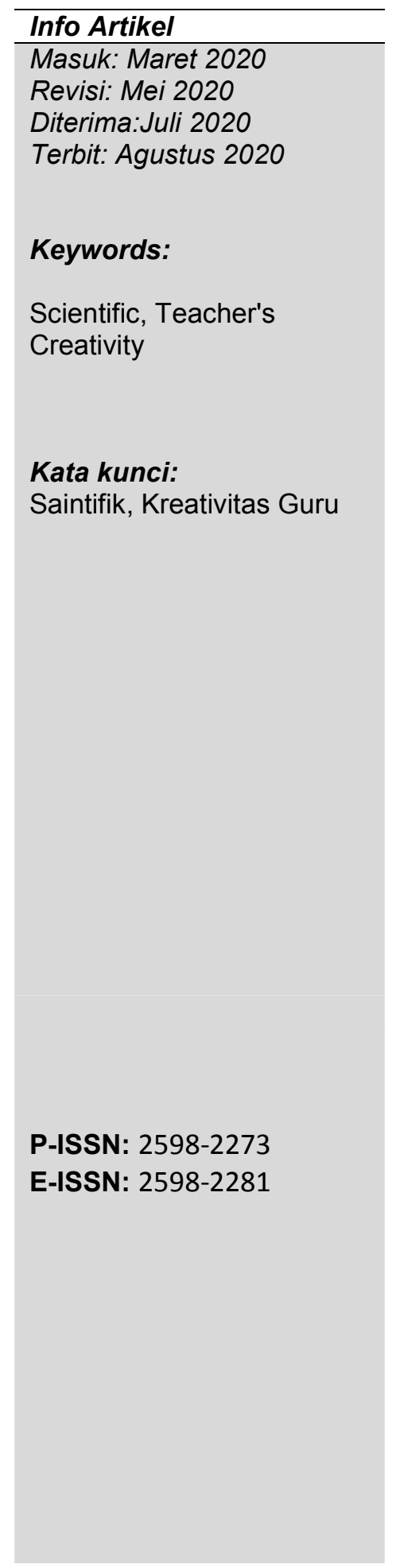

\begin{abstract}
Abtract
Community Service Disablement was held with the aim of providing educator creativity deepening in the implementation of scientific learning in the 2013 curriculum. This service is a follow up to previous research that has been carried out on improving teacher creativity in implementing the 2013 curriculum. The implementation of community service is preceded by coordination with the leadership institutions and cooperation agreements in various fields one of which is training through community service. In this dedication activity carried out at RA Al Islam 3 Gebang, this service uses collaborative methods by conducting information retrieval to find out teachers' understanding of the creativity of educators in scientific learning in the implementation of the 2013 curriculum. Then practice the learning activities with santifik learning. The follow-up will be carried out by students to monitor the extent of the spread of science and technology that has been given The result of this Disablement is an increase in teacher understanding of the need to increase teacher creativity in implementing a 2013 curriculum-based scientific approach. So that teachers can design and implement learning with a creative scientific approach, it is hoped that the science and technology delivered can be shared by partners.
\end{abstract}

\footnotetext{
Abstrak

Pengabidan Kepada Masyarakat ini diadakan dengan tujuan untuk memberikan pendalaman kreativitas pendidik dalam pelaksanaan pembelajaan saintifik pada kurikulum 2013. Pengbdian ini sebagai tindak lanjut dari penelitian sebelumnya yang telah dilaksanakan tentang peningkatan kreatifitas guru dalam pelaksanaan kurikulum 2013. Pelaksanaan pengabdian pada masyarakat ini didahului dengan koordinasi kepada pimpinan lembaga dan melakukan perjanjian kerja sama dalam berbagai bidang salah satunya pelatihan melalui pengabdian pada masyarakat ini.

Pada kegiatan pengabdian ini dilaksanakan di RA Al Islam 3 Gebang, pengabdian ini menggunakan metode kolaboratif dengan melakukan pengalian informasi untuk mengetahuai pemahaman guru tentang kreativitas pendidik dalam
} 
pembelajaran saintifik pada implementasi kurikulum 2013. Dilanjut dengan memberikan materi mengenai kreativitas pendidik dalam pembelajaran saintifik pada implementasi kurikulum 2013. Kemudian mempraktekan kegiatan pembelajaran dengan pembelajaran santifik. Tindak lanjutnya akan dilakukan monitoring oleh mahasiswa seberapa luas penyebaran IPTEK yang telah diberikan

Hasil dari Pengabidan ini adalah peningkatan pemahaman guru tentang perlunya peningkatan kreativitas guru dalam melaskanakan pendekatan saintifik berbasis kurikulum 2013. Sehingga guru dapat merancang dan melaksanakan pembelajaran dengan pendekatan saintifik yang kreatif, harapanya Iptek yang telah disampaikan dapat di sebarkan oleh mitra.

\section{PENDAHULUAN}

Pembelajaran di Lembaga PAUD pada saat ini telah mengalami perkembangan yang cukup besar dalam rangka optimalisasi perkembangan anak usia dini, dalam penerapan kurikulum 2013 yang menuntut guru untuk dapat menerapkan pembelarajan yang inovatif dengan pendekatan saintifik.

RA AL Islam 3 Gebang merupakan lembaga pendidikan yang berkembang dengan baik di lingkungan Kec. Banjarsari Kab. Surakarta. RA AL Islam 3 Gebangyang letaknya dipinggir jalan besar cukup strategis. Lembaga yang di pimpin kepala sekolah yang sudah berlatang belakang pendidikan $s 1$ pendidikan, dengan 7 pendidik ini mempunyai siswa berjumlah 80 yang dibagi dalam 4 kelas. Hal ini dapat disimpulkan bahwa lembaga ini berkembang cukup baik.

Taman Kanak-kanak (TK) dan Kelompok Bermaian (KB) sebagai lembaga pendidikan formal dan non formal untuk anak usia dini, mempunyai fungsi salah satunya adalah mengembangkan berbagai aspek, seperti perkembangan bahasa, seni, fisik motorik, kognitif, sosial emosi dan moral. Kehadiran PAUD sangat penting untuk perkembangangan anak. Hal ini dikarenakan di PAUD anak pertama kali keluar dari lingkungan rumah. KB-TK berperan penting karena pada perkembangan manusia adalah merupakan tahapan awal dalam memasuki tahapan perkembangan selanjutnya. Oleh karena itu salah satu tujuan di PAUD adalah mempersiapkan anak ke jenjang pendidikan selanjutnya, yaitu pendidikan dasar.

Setiap anak membawa keunikan yang berbeda dengan anak lainnya. Hal tersebut dikemukakan Inisiator dan Pembimbing Komunitas Anak Gifted, Dr Drg Julia Maria Van Tiel kepada Tribun Jogja, Selasa (18/10/2016 dalam http://jogja.tribunnews.com/2016/10/18/setiap-anak-lahir-dengan-potensi-dankeunikan-berbeda) Mereka membawa kelebihan yang berbeda-beda.. Tugas orang tua dan pendidik adalah mengenali potensi setiap anak dan dapat 
mengembangkannya agar menjadi lebih baik. Potensi anak inilah yang diharapkan dapat ditemukan oleh pendidik dan orang tua sedini mungkin.

Berdasarkan hasil identifikasi terhadap khalayak sasaran ternyata masih banyak guru KB dan TK yang belum memenuhi kualifikasi akademik dan kompetensi sebagaimana diamanatkan dalam Peraturan Pemerintah tersebut. Pengalaman mengajar guru TK dan KB yang memiliki kualifikasi akademik SMA/Sederajat pada umumnya sudah mengajar diatas lima tahun. Sedangkan pengalaman pelatihan terkait profesi yang diemban masih sangat minim. Kualifikasi akademik, pengalaman mengajar, pengalaman pelatihan yang relevan serta kompetensi yang tidak memadai berpengaruh terhadap kualitas pembelajaran matematika yang diselenggarakan oleh guru KB dan guru TK tersebut.

Tingginya tuntutan orang tua terhadap kemampuan membaca, menulis dan berhitung di lembaga KB dan TK. Berdasarkan hasil wawancara yang dilakukan secara informal terhadap guru-guru di lapangan menunjukan bahwa sebagian besar orang tua menginginkan agar anak memiliki keterampilan membaca, menulis dan berhitung. Alasan yang mendorong tingginya tuntutan ini antara lain adalah sebagai persyaratan memasuki sekolah dasar.

Rendahnya kreativitas guru dalam melaksanakan kegiatan pembelajaran, pembelajaran yang dilaksanakan pada saat ini adalah berdasarkan kurikulum 2013 yang menggunakan pendekatan saintifik, pendekatan saintifik ini perlu menuntut guru untuk kreatif dalam mengemas pembelajaran saintifik tersebut, nyatanya bahwa pembelajaran saat ini hanya sebatas apa adanya. Saintifik belum terlaksana dengan optimal karena kurangnya kreativitas sehingga seakan pembelajaran anak-anak berkesan secara tertulis (paper pencils test) dan latihan-latihan terstruktur (drill). Sehingga kesempatan penemuan anak dalam bermain kurang.

Menyadari akan pentingnya kreativitas guru dalam melaksanakan pembelajaran saintifik, maka perlu dilakukan upaya yang dapat menambah pemahaman guru dengan pelatihan kreativitas pendidik dalam pelaksanaan pembelajaran saintifik yang dapat menambah pengetahuan dan ketrampilan yang dapat mengoptimalkan perkembangan anak.

\section{METODE PELAKSANAAN}

Metode pelaksanaan yang dapat digunakan dalam pengabdian ini adalah dengan pelatihan dan pendampingan. Berikut ini adalah tahapan pelatihan yang dilakukan: 


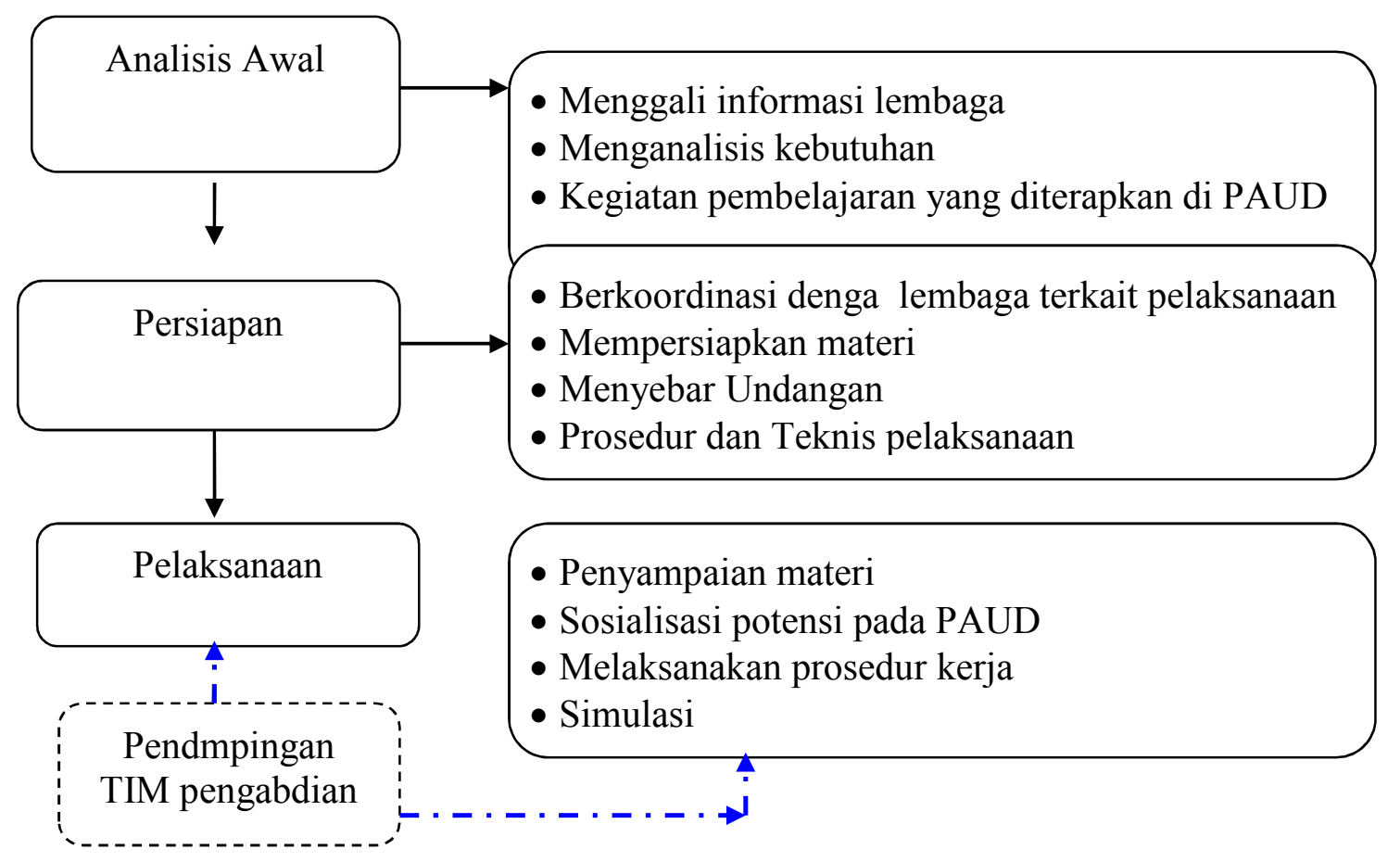




\section{PEMBAHASAN}

Untuk mengetahui penguasaan materi pada guru yang disampaikan diadakan pre test dan post test. Pre test dilakukan untuk mengetahui sejauh mana pemahaman guru secara umum untuk dapat menjadi patokan seberapa kedalaman materi yang akan di sampaikan dan postest dilakukan untuk mengetahui seberapa besar pemahaman peserta setelah mendapatkan materi. Berdasarkan hasil Pretes, diketahui bahwa guru masih belum mendalamai kreatifitas dalam pelaksanaan pendekatan saintifik pada pembelajaran di PAUD. Terkadang guru bigung dalam menyampikan materi-materi tertentu tentang bagaimana mengajarkannya dengan pendekatan saintifik di contohkan pada materi pakaian ku guru terbatas bagaimana pelaksanaan pembelajarannya kurang mengali lebih dalam lagi.

Tabel Tingkat Pemahaman Orang Tua dan Guru

\begin{tabular}{|l|l|l|l|}
\hline Materi & Pre tes & Post Tes & $\begin{array}{l}\text { Pasca } \\
\text { Pendampingan }\end{array}$ \\
\hline Kreatifitas & $25 \%$ & $75 \%$ & $95 \%$ \\
\hline Pendekatan saintifik & $55 \%$ & $80 \%$ & $95 \%$ \\
\hline
\end{tabular}

Dari total semua jumlah peserta, sekitar $70 \%$ peserta tidak / belum begitu paham dan sisanya $30 \%$ sudah lebih paham. Setelah kegiatan di peroleh informasi bahwa data tersebut meningkat sebesar $75 \%$ peserta telah memahami dan menyadari kreatifitas dalam pendidikan anak dini dan mampu melakukan identifikasi dan memberikan stimulasi yang benar agar perkembangan anak menjadi optimal

Maka berdasarkan kegiatan pengabdian yang dilakukan berdasarkan per test dan post tes tampak bahwa pemahaman peserta telah mengalami peningkatan yang cukup baik dan akan dilakukan pemantauan dan pendampingan oleh tim pengabdian masyarakat selama 2 bulan untuk mengetahui peningkatan karakter anak-anak dan mengetahui kendala yang dialami oleh peserta pengabdian masyarakat ini.

Setelah dilakukan pendampingan selama 2 bulan, berdasarkan pengamatan dan wawancara sebagai bahan evaluasi selama kegiatan pendampingan diperoleh informasi bahwa guru mampu melaksanakan penedektan saintifik dengan lebih kreatif dan mampu mengunakan bahan-bahan yang terdapat di sekitar anak untuk pembelajaran dengan pendekatan saintifik tersebut.

Berdasarkan hasil pengabdian dapat disimpulkan bahwa guru diharapkan mampu terus berinofasi kreatif dalam pembelaran serta persebaran iptek telah meluas dengan diadakan penyampaian materi kembali di forum profesi guru IGRA kecamatan yang dihadiri oleh sejumlah guru di lembaga se-kecamatan Banjarsari yang difasilitasi oleh Kemenag Surakarta.

Berdasarkan paparan diatas, dapat disimpulkan bahwa kegiatan pengabdian memberikan pendalaman kreatifitas guru dalam pembelajaran saintifik dapat meningkatkan mutu pendidikan anak usia dini dan membantu mengembangkan perkembangan anak lebih optimal.

Setiap kegiatan pasti melalui tahapan yang telah disusun agar tercapai keberhasilan seperti yang diharapkan. Sama halnya pada kegiatan ini masih diperlukan tahapan selanjutnya. Kegiatan pada tahap selanjutnya adalah mengadakan kegiatan serupa, tetapi dengan tema yang berbeda. Kegiatan selanjutnya adalah workshop karakteritik kurikulum pembelajaran lembaga. 
Disamping itu perlu juga kegiatan produktif seperti pelatihan penbuatan Alat Peraga Educatif (APE).

Rencana tahapan berikutnya adalah memberikan pendampingan bagi lembaga lain yang belum jelas tentang kreatifitas penerapan pendekatan saintifik menjadi semakin jelas melalui kegiatan workshop. Melalui pengabdian ini diharapkan permasalahan yang dihadapi guru dapat diatasi.

\section{PENUTUP}

Berdasarkan pelakasanaan pengabidan kepada masyarakat yang telah di laksanakan maka dapat disimpulkan : 1) Perlunya pemahaman tentang pendekatan saintifik pada guru, sehingga dapat memberikan pendidikan dan pengasuhan sesuai kebutuhan anak. 2) Pendidik perlu selalu mengembangkan kreatifitas dalam pembelajaran untuk tercapaiknya perkembangan anak yang optimal. 3) Melalu pengabdian masyarakat guru dapat memahami bahwa anak seharusnya mendapatkan pengetahuanya sendiri memalalui bimbingan dengan kegiatan ekploratif seperti pendekatan saintifik

\section{DAFTAR PUSTAKA}

Direktorat Pembinaan Pendidikan Anak usia dini. 2011. Petunjuk teknis Orientasi teknis peningkatan pemahaman program penguatan PAUD berbasis keluarga (Parenting). Kementrian pendidikan nasional.

Hurlock, Elizabeth B. 1995. Perkembangan anak jilid 1 dan 2. Jakarta : Penerbit Erlangga. Terjemahan, Editor Agus Dharma. Judul asli: Child evelopment

Kementerian Riset, Teknologi, dan Pendidikan Tinggi. 2016. Panduan Pelaksanaan Penelitian dan Pengabdian kepada Masyarakat di Perguruan Tinggi. Edisi X Tahun 2016

Yuliani Nurani Sujiono, MPd. 2011. Konsep Dasar Pendidikan Anak Usia Dini. Indeks

Anonim. 2011.Konsep, Fungsi Dan Prinsip Bimbingan Di Taman Kanak-Kanak https://massofa.wordpress.com/2011/01/05/konsep-fungsi-dan-prinsipbimbingan-di-taman-kanak-kanak/.. Di akses tanggal 16 Januari 2018.

http://jogja.tribunnews.com/2016/10/18/setiap-anak-lahir-dengan-potensi-dankeunikan-berbeda. setiap anak lahir dengan potensi dan keunikan berbeda. selasa, 18 oktober 2016 23:54 